\title{
Effects of teachers' readiness in teaching and learning of entrepreneurship education in primary schools
}

\begin{abstract}
Teachersô readiness in teaching and learning is very important in producing and creating effective teaching and learning methods, especially towards the mastery, practices and cultivation of entrepreneurial values among primary school students. Therefore, this paper will be discussing on a study of teachers' readiness in teaching and learning of entrepreneurship education in primary schools (KHSR) in Petaling Utama, Petaling Jaya, Selangor area. A set of questionnaire was used as the research instrument to assess the level of teachers' readiness in teaching and learning of KHSR in primary schools. The study showed that the level of teachersô readiness in teaching and learning of entrepreneurship education KHSR is on the moderate level.
\end{abstract}

Keyword: Entrepreneurship education in primary school; Teachers' readiness 